\title{
Significance of New Education Policy (NEP) 2020 for Adult Education and Lifelong Learning Program
}

\author{
Renu Gandhi \\ Assistant Professor (Selection grade), Department of Lifelong learning and Extension \\ (DLLL\&E), Panjab University, Chandigarh, 160014, India \\ ORCIDID: 0000-0001-9040-1083, Email id: renunidhigandhi@gmail.com
}

Area/Section: Education Management.

Type of the Paper: Review Article.

Type of Review: Peer Reviewed as per $|\mathrm{C}| \mathrm{O}|\mathrm{P}| \mathrm{E} \mid$ guidance.

Indexed in: OpenAIRE.

DOI: https://doi.org/10.5281/zenodo.6167835

Google Scholar Citation: $\underline{\text { IJMTS }}$

\section{How to Cite this Paper:}

Renu Gandhi, (2022). Significance of New Education Policy (NEP) 2020 for Adult Education and Lifelong Learning Program. International Journal of Management, Technology, and Social Sciences (IJMTS), 7(1), 79-95. DOI: https://doi.org/10.5281/zenodo.6167835

International Journal of Management, Technology, and Social Sciences (IJMTS) A Refereed International Journal of Srinivas University, India.

CrossRef DOI: https://doi.org/10.47992/IJMTS.2581.6012.0179

(C) With Author.

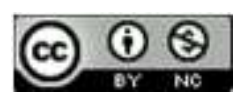

This work is licensed under a Creative Commons Attribution-Non-Commercial 4.0 International License subject to proper citation to the publication source of the work.

Disclaimer: The scholarly papers as reviewed and published by the Srinivas Publications (S.P.), India are the views and opinions of their respective authors and are not the views or opinions of the SP. The SP disclaims of any harm or loss caused due to the published content to any party. 


\title{
Significance of New Education Policy (NEP) 2020 for Adult Education and Lifelong Learning Program
}

\author{
Renu Gandhi \\ Assistant Professor (Selection grade), Department of Lifelong learning and Extension \\ (DLLL\&E), Panjab University, Chandigarh, 160014, India \\ ORCIDID: 0000-0001-9040-1083, Email id: renunidhigandhi@gmail.com
}

\begin{abstract}
Purpose: Adult Education Program is an imperative platform to spread literacy, raising awareness, functional amenabilities and sensitize each member of the community irrespective of age, region and religion. National Adult Education Program (NAEP) was initiated on $2^{\text {nd }}$ October, 1978 to spread literacy among community belonging to the age groups 15-35 years. However, with emergence of various implementing challenges and demands of the community, Adult Education was transfigured to Lifelong learning to engulf people of all age groups and all regions with special emphasis on socially and economically deprived sections of the community.

Design/ Methodology/ Approach: Present review highlights the role of New Education Policy (NEP) 2020 in proliferating adult education and lifelong learning programs in the current digital world. The emergence of Digital India and Atma Nirbhar Bharat makes it indispensable for each member of the community to be well aware of the basic skills that are imperative to be an independent and useful member of the society. To address the unforeseen challenges observed in India's education landscape after COVID-19 pandemic scenario, it become inevitable to sensitize each member of the community with updated knowledge and skills.

Findings/Result: As explained by Maclver who was a member of American Sociological Society, has explained the concept of society as a web of social relations. Current scenario has made it imperative to realize the significance of Adult education and lifelong learning. The author suggested that Adult Education and Lifelong Learning is a web of Skill Development Program. In current digital India and Atma Nirbhar Bharat, where technology advancements has emerged on a significant height, Adult Education and Life Long Learning plays a vital role in making the society economically independent.
\end{abstract}

Originality/New knowledge: The novelty in current review and NEP 2020 lies in transition from National Education Policy 1986 aiming at spreading functional literacy among community to NEP 2020 aiming at enhancing skill development and dissemination of skill development programs among community to make them economically independent and a useful member in the society.

Paper type: Review Article

Keywords: New Education Policy, Adult Education, Lifelong learning, Digital India, Community, Literacy.

\section{INTRODUCTION :}

The sudden overdependence on technology with emergence of Digital India has brought with it various bottle necks that need to be overcome to have equity among all members of the society [1]. Literacy and skill development are two stringent veritable to be worked upon for building a participant, inclusive and vibrant community $[1,2]$. Saakshar Bharat Mission (SBM) launched on $8^{\text {th }}$ September, 2009 (International Literacy Day) by Government of India especially for the districts having low female literacy rates of $\approx 50 \%$ or below. Lifelong learning policy in India has slow evolution due to lack of its articulate picture in terms of nomenclature and disciplinary status and its correlation with Adult and Continuing Education Program. The five phases namely; Concept of Basic Literacy (1882-1947), Concept of Social Education (1948-64), Concept of Functional Literacy (1965-77), Concept of Developmental Literacy (1978-2008) and Concept of Lifelong Learning (2009 onwards) determine the 
various evolution phases of Adult Education Program. Concept of Basic Literacy was in the preindependence era with focussed curriculum on 3 R's of reading, writing and arithmetic skills. The stories demonstrating historical significance, health, hygiene, first aid practices and basic etiquettes were also the part of this curriculum. The second phase Concept of Social Education was an integrated program with Community Development Program and emphasized on social education inculcating significant social aspects of the society. Further evolution towards revitalizing education paradigm was made with initiation of the Concept of functional literacy. Functional literacy integrates literacy with the occupation of the learner and beginning of implementing this project started with Farmers Training and Functional Literacy Project (FTFLP). This was done to integrate a clientele in proliferation of agriculture research and development (R\&D) by sensitizing farmers about the various agrochemical products, identify labels of fertilizers, amenability to read popular useful agriculture articles and magazines. All these consolidations will spur assets to their agriculture production and hence their unequivocal contribution in ensuring food security of India. National Adult Education Programme (NAEP) was conceived in India during the fifth phase of Concept of Developmental Literacy aiming to contribute towards liberation and overall development of each community member. The policy support to Adult Education research was identified in 1980s and acceleration of research in adult education evolved in 1991s. National Policy on Education 1986 mentions that adult education would assure the parities in social, gender and economic parameters. The Program of Action (1992) states that the accentuation in adult education program should be on skill development, awareness generation among the learners of national objectives, liberation from oppression and other development activities. This implies that not only social development, but it also aimed to create awareness among people about various policies, law, rights and duties of the government and people for successive implementation of the strategy of redistributive justice. From 2009 onwards, to achieve the aim of dwindling the nonliterate groups, communities were spurred to develop lifelong learning paradigm approach to foster a niche environment for striding towards ameliorate education system. The New Education Policy (NEP) 2020 has been drafted to integrate lucrative output in the education system in current digital India [35]. Especially various impediments arising due to online banking and transactions frauds and deplorable activities makes it indispensable to spread awareness, literacy and basic skills to each member of a society [5-7].

\section{OBJECTIVES OF THE PAPER :}

(i) To understand the role of NEP 2020 in promoting Adult literacy and lifelong learning programs in India.

(ii) Analyzing various platforms imperative to foster growth and development of Adult Education and Lifelong learning programs.

(iii) Various policies and impact of implementation strategies for success of these programs.

\section{METHODOLOGY OF DATA COLLECTION AND ANALYSIS :}

The data collection and key features related to Adult education and lifelong learning approaches and policies were taken from the reported literature in the research papers and policy reviews. The theories and approaches utilized and reviewed by the authors and researchers was clubbed in a tabular form and analyzed step by step. Impact of versatile parameters inculcating social, economic, political, digital framework, literacy training paradigms, gender parity and many others are taken into account while analyzing their role in NEP 2020 for adult learners.

\section{RELATED WORK :}

\subsection{Role Of Nep 2020 In Adult Education And Lifelong Learning}

The National Literacy Mission launched in 1988 inculcated voluntary support and participation that resulted in significant amendment in national literacy from 1991-2011. It further elucidated the need of the concept of lifelong learning in dynamic world with seizure challenges to work upon $[1,2]$. NEP 2020 proposes a complete articulate paradigm curriculum of adult education by NCERT with at least 5 types of programs namely; foundational literacy and numeracy, basic education, critical life skills, vocational skills development and continuing education. The framework for these programs will be envisioned on the basis of adult learners. Appropriate infrastructure like special Adult Education centres (AECs) and Vocational Training centres (VTCs) with an incentivizing and easy access to the adult 
learners will be spurred. Recruitment of well trained, skilled and high qualified teachers for imparting the above mentioned 5 program skills to the adult and lifelong learners will be the paradigm approach to be followed. Innovative polices competitive with seizure technologies and quagmire challenges with diligent participation of community in achieving the aim of $100 \%$ literacy to be followed by NEP 2020 $[8,9]$. The sharing of infrastructure of educational institutes like schools, colleges, vocational centres and other skill development centres will be imperative to ensure well utilization of human resource, existing resources and amend the efficacy of the program $[3,5]$. Proper shackling, monitoring and supervising team for the instructors of Adult education and lifelong learning programs will be followed to ensure successful implementation of these programs. Especially the role of social activists and social councillors to track and ensure the tapping of school dropouts and non-enrolled students will be an imperative source to achieve this aim. Easy access and availability of online and offline books to the community is imperative to inculcate the habit of reading among community members and educational institutions. In this context, the policy recommends strengthening and modernizing of all educational institutes libraries including the public libraries. It will be the responsibility of the central and state government to monitor the affordable cost price of these books and their distribution strategies to ensure it access and availability to the people belonging to each section of the society, especially the disadvantaged section of the society. Quality and updated technology will be utilized for adult learners to undertake the objective of Digital India and Atma Nirbhar Bharat. It will include updating and strengthening existing libraries and creating animated online courses, modules, learning apps, e-books, satellite based TV channels, ICT equipped libraries and other adult and lifelong learning centres. Both governments, philanthropic and other crowd sourcing initiatives will form a consortium to undertake this process.

\subsection{Platforms Required For Adult Education And Lifelong Learning Program}

The rising life expectancy, reducing early retirement and prolonged employment age, revolution in digital technology in the past ten years has elicited the significance of lifelong learning for adult members of the community [10,11]. Various impediments and perspectives have been reported for better learning at advanced education levels to keep one updated with seizure technologies [12]. A particular issue that need to be contemplated to ensure quality education is to shackle the teaching methodologies and infrastructure of educational institutes and universities [12]. Especially the proletariat class need to be updated with current skill education to be a useful member in the society [13]. Therefore, current government policies are targeted towards innovative approaches of lifelong learning towards adult learners to retain them in employment sector and utilizing their skills wisely [10]. Hieronymus et al. [14] have reported the influence of four factors incentivizing adult education program namely; requirement to seek democracy deliberately, significance of vital communities, efficacy of groups and enabling mature adults [14]. It aims in inculcating the responsible behaviour in terms of group leader and group participator in any community group or program working towards a better society [14-16]. The classifications of state and local organizations role in proliferating adult education programs lies in establishment of strong adult education leadership in the state departments of education, consultancy services, dissemination, research and financial access by state organizations and restricted to specific community for local organizations, respectively [14-16]. Midtsundstad et al. [10] has reviewed the impact of formal adult learning programs on employment sector and labour market participation and have found strong correlation of the basic skills imparted to them with their output efficacy. Bratsberg et al. [17] has reported an imperative contribution of vocational uppersecondary education in averting unemployment risks with amended opportunities of re-employment for adult learners. Picchio et al. [18] has also emphasized the role of various training centres and other training firms for increasing employment opportunities for the community. The organizations undertaking the job of research in Adult Education are Indian Council for Social Science Research, University Grants Commission (UGC), Department of Social Welfare and Women, NITI Ayog, Commonwealth bodies, National Council of Educational Research and Training, United Nations Educational Scientific and Cultural Organization (UNESCO), United Nations Development Program (UNDP) and International Labour Organization (ILO). The aim of these research organizations is to generate evidence based data in determining the illiteracy rates in various regions and different economic sections of the society and their various causes and impact. In addition, a strong need to bridge the gap between research and practice is imperative and be implemented to ensure appropriate 
spur and success of adult literacy program among community [19-21]. Hieronymus et al. [14] has elucidated the age criteria for grasping, learning and acquiring significant skills by the community and emphasized the role of perceiving and learning by the adult learners. Dickson et al. [22] has articulated the role of arts and creativity in making learning innovative and interesting for adult learners, which will help them to learn faster and integrate incentives for better learning. This concept is also followed by NEP 2020 for both pre-school education and lifelong learning programs as it allows incentive steps to prevent school dropouts in due course of time [22, 23].

\subsection{Special Needs and Approaches For Adult Learners}

Interactive learning environments have certain approaches and protocols to be followed by to efficiently sensitize adult learners. Case studies conducted in this paradigm emphasize an imperative requisite of personal, social and educational amendments in adult education and lifelong programs $[24,25]$. There are various approaches followed in Adult Education and Lifelong learning programs [26-30]. These approaches are imperative to empower amenable skills in adults to be more marketable for employment opportunities [26-28]. In addition, self-control, patience and psychological factors play a vital role in imparting self-directed learning to adult learners [29, 30]. Creativity and utilization of music in imparting education in such programs integrate significant inputs in this domain [31-33]. This is because it not only makes learning easy, entertaining and interesting but also helps in solving various mental problems of adult learners [34-40]. Shubenkova et al. [36] has made categorical differentiation of adult learners on the basis of age groups, generations and its special education needs (as depicted in table 1) and various approaches followed in this domain (table 2). The aim of Saakshar Bharat/Adult Education Policy is to spread literacy among society by targeting non-literate and neo-literate of 15 years and above [41]. Lifelong learning forms a consortium of both formal and non-formal education inculcating training and skill development [42]. Therefore, needs of adult education program and learners are dependent on the levels of learning contributing to sustainable development and poverty alleviation [43]. The competencies to acquire skills and amend their existing skills enable them to increase income of the community as better skills and higher education levels are a proxy for more skills and generate higher incomes [44-46]. Various concepts of Adult learning inculcating real-life learning, self-directed learning, learning-how-to-learn, andragogy and other learning strategies are vital approaches for conducting an interactive adult education program [47-50]. Table 3 lists the details and significance of these concepts for adult learners.

Table 1: Different categories of Adult and Lifelong Learners

\begin{tabular}{|c|c|l|}
\hline $\begin{array}{c}\text { Category } \\
\text { number }\end{array}$ & Category Age group & \multicolumn{1}{c|}{ Category Type } \\
\hline 1 & $18-25$ & $\begin{array}{l}\text { To be provided with suitable and sufficient education } \\
\text { opportunities. } \\
\text { To provide suitable employment opportunities and } \\
\text { trainings for skills enhancement. }\end{array}$ \\
\hline 2 & $25-45$ & $\begin{array}{l}\text { Enhancing professional skills to make them markedly } \\
\text { independent }\end{array}$ \\
\hline 3 & Above 45 & $\begin{array}{l}\text { Mutual teaching with interaction from } 1^{\text {st }} \text { and } 2^{\text {nd }} \\
\text { categories }\end{array}$ \\
\hline
\end{tabular}

Table 2: Various approaches followed for Adult Literacy and Lifelong program are:

\begin{tabular}{|c|c|l|l|}
\hline $\begin{array}{c}\text { S. } \\
\text { No. }\end{array}$ & Teaching Method & \multicolumn{1}{|c|}{ Approach adopted } & \multicolumn{1}{|c|}{ Remarks } \\
\hline 1. & Knowledge & $\begin{array}{l}\text { Brainstorming sessions in } \\
\text { groups, Focussed group } \\
\text { discussions, Lectures, seminars } \\
\text { and demonstrations }\end{array}$ & $\begin{array}{l}\text { Aim is to collect creative ideas } \\
\text { in groups to impart quality and } \\
\text { skilled education }\end{array}$ \\
\hline 2. & Understanding & $\begin{array}{l}\text { Home reading tasks, Focusing } \\
\text { specific topics, discussions in } \\
\text { small knowledge circles }\end{array}$ & $\begin{array}{l}\text { Aim is to understand specific } \\
\text { situations and relevant } \\
\text { knowledge among specific } \\
\text { topics }\end{array}$ \\
\hline
\end{tabular}




\begin{tabular}{|c|l|l|l|}
\hline 3. & Skills & Paradigm study contract & $\begin{array}{l}\text { Aim is to provide pre- } \\
\text { determined and contract skills } \\
\text { depending on professional } \\
\text { background and applied skill }\end{array}$ \\
\hline 4. & Value & $\begin{array}{l}\text { Sensitizing sessions in groups, } \\
\text { Small knowledge circle } \\
\text { discussions }\end{array}$ & $\begin{array}{l}\text { Evaluation and priorities } \\
\text { added to skills impartment } \\
\text { sources }\end{array}$ \\
\hline 5. & Attitude & $\begin{array}{l}\text { Analyzing certain situations with } \\
\text { their responses }\end{array}$ & $\begin{array}{l}\text { Group members are } \\
\text { encouraged to share their ideas } \\
\text { and thoughts on a common } \\
\text { problem discussed in groups. }\end{array}$ \\
\hline
\end{tabular}

Table 3: Different Concepts of Adult Education and Lifelong Learning

\begin{tabular}{|l|l|l|}
\hline Concept & Detail & Significance \\
\hline Real life learning & $\begin{array}{l}\text { Learning from daily experiences, dilemmas } \\
\text { and opportunities }\end{array}$ & $\begin{array}{l}\text { This informal teaching } \\
\text { experience makes them self- } \\
\text { reliant to handle practical } \\
\text { situations wisely. }\end{array}$ \\
\hline $\begin{array}{l}\text { Self-directed } \\
\text { learning }\end{array}$ & $\begin{array}{l}\text { Initiative is taken from the learner as per } \\
\text { his/ her learning needs without seeking } \\
\text { anyone's help. Learners identify the } \\
\text { resources and parameters imperative for his } \\
\text { learning strategy. }\end{array}$ & $\begin{array}{l}\text { It allows a learner to explore all } \\
\text { lhearning paradigm and gives } \\
\text { freedom of speech, expression } \\
\text { and innovation. }\end{array}$ \\
\hline $\begin{array}{l}\text { Learning-how-to- } \\
\text { learn }\end{array}$ & $\begin{array}{l}\text { To help learners to acquire knowledge and } \\
\text { skills in paradigm manner as per requisite } \\
\text { of profession and training process. } \\
\text { Planning, Conducting and Evaluating are } \\
\text { three imperative systematic paradigms } \\
\text { followed in this formal education approach. }\end{array}$ & $\begin{array}{l}\text { Teaching-learning exchange and } \\
\text { practicing training skills in } \\
\text { appropriate formal education } \\
\text { program helps learners to } \\
\text { achieve the goal and specific } \\
\text { target set by them or their } \\
\text { mentor. }\end{array}$ \\
\hline Andragogy & $\begin{array}{l}\text { Understanding the art and science of } \\
\text { training adult learners Self-concept, } \\
\text { experience, learning readiness and } \\
\text { knowledge adaptation are the key } \\
\text { parameters identifying andragogy of a and } \\
\text { learner. }\end{array}$ & $\begin{array}{l}\text { Andragogy is significant } \\
\text { parameters to identify the type } \\
\text { of program to be implemented } \\
\text { for a specific learner. }\end{array}$ \\
\hline $\begin{array}{l}\text { Learning styles and learning strategies } \\
\text { decide the learning situation and ability of } \\
\text { an adult learner }\end{array}$ & $\begin{array}{l}\text { Learning techniques are selected } \\
\text { depending on amenability of a } \\
\text { learner. }\end{array}$ \\
\hline
\end{tabular}

\section{COMPARISON OF NEP 2020 WITH EXISTING POLICIES IN THE CONTEXT OF ADULT EDUCATION AND LIFELONG LEARNING :}

NEP 2020 aims in promoting lifelong learning and adult education to avert obsoleteness in individuals in terms of modern skills, updated knowledge, maturity and satisfaction in their lifestyles [5, 50-52]. Educability, opportunity and motivation are three imperative paradigms for successful functioning of adult education program [52-55]. Vocational training to help individuals to develop ample skills with productive value and economic opportunities acts as suitable incentives to promote self-reliance among adults [56-59]. Therefore NEP 2020 has integrated this paradigm platform which was not emphasized in existing NEP 1986. Strawn et al. [60] has elaborated the various policies promoting the proliferation of Adult Education Program. He has emphasized the role of post-secondary education, training and workforce development institutions to support community in employment sector to support their families [61-63]. For instance, after digital India and COVID pandemic, utilization of mobile smart phones has become an imperative skill for each member of a society in one form or the other [63]. Therefore, digital coding, imparting online and tech-savvy skills are significant assets for a lifelong 
learning program [64-66]. Different Pedagogic practices emphasizing on adult learners strength and enhancing their skills, instead of working on their deficits will prove to be an incentive approach for lifelong learners [67, 68]. Amaral et al. [69] has reported a critical comparative analysis of 54 lifelong learning policies that have been implemented in around 9 European countries. The impacts, effects and responses of adult learners and their correlation with objectives and orientations of these programs have been discussed in detail. Lifelong learning policies in the recent scenario aim at structuring, preparing, correcting and improving transitions towards labour market from education, especially for early school leavers helping them to earn employment with appropriate and sufficient training [69-72]. Economic growth and social inclusions are two imperative parameters tapped upon in current lifelong learning policies [73-75]. Individuals not in education, employment nor training referred as NEETs are targeted in NEP 2020 with employment centred polices with an objective of individual guidance, activation and life course de-standardisation [76-78]. It aimed with an articulate of amending employability opportunities for the community, irrespective of his/ her educational background, lifestyle and amenability $[79,80]$. However, as per the feedbacks and responses received from the targeted groups, policies should be drafted based on research data and evidence based approaches from both state level and national level situations. This is because it's imperative to understand the role, impact and functioning paradigm of each state in amending quality education and skills impartment strategies to the community [81-86]. The role of gender parity and equal participation of women in adult education program is another imperative approach to foster proliferation of adult education projects [87-90]. This is because social impact on adult literacy project has been reported by the researchers to affect implementation mechanism of lifelong learning projects [90-93].

\subsection{Various policies and impact of implementation strategies for success of Adult Education and Lifelong Learning Programs}

Adult Education Program is not a new concept. Various policies have been introduced and amended by the government from time to time in the name of Social Education, National Adult Education Program, National Adult Education Program for Education, Total Literacy Campaign (Adult Literacy Program) and National Literacy Mission [94, 95]. These programs implemented functional literacy among adults because at that time around 44 crores population of India was illiterate in the age group 15-35 years. For instance, the key concept initiated in 1947 was "Basic Education" based on traditional approach and night schools. In the year span of 1949 to 1966, it transformed to "Civic Literacy" emphasizing on Social Education. In the next 10 years from 1966 to 1977 "Functional Literacy" concept was initiated emphasizing on versatile functional literacy programs, Shramik Vidyapiths and Farmers Education. Total Literacy Campaigns started from 1978 onwards were based on the concept of "Development Literacy" following social change approach. National Adult Education Program (NAEP) was formulated by the government in 1978 and in 1980s University Grants Commission (UGC) bestowed significant funding grants to 93 Universities to promote an expansion in University Adult Education in India. Rural Functional Literacy Programme (RFLP) launched in May 1986 as a sub-program of Adult Education Program funded by central governments and implemented by Union Territories (UTs) and states. RFLP was based on the principle of "Each one Teach One" and involved various National Service Scheme (NSS) workers and student volunteers of colleges and Universities to make this program successful. National Literacy Mission (NLM) launched on May, 1988 aiming in imparting functional literacy to around 80 million illiterate community lying in 15-35 age groups by 1995. NLM achieved $80 \%$ success rate in 1995 which was an impressive value as compared to $36 \%$ success rate in 1981. However slow success in the past programs and polices lies in planning measures at state level and not appropriate absorption and implementation interests and strategies at district and village levels $[96,97]$. Therefore, presently the focus of Adult Education Program has been shifted towards literacy program focusing Skill Development Program. It will not only incentivize successive participation form villages and districts to adopt and implement these programs, but will also involve state, districts and village representatives to participate significantly in these programs. This is because skill development programs are an imperative source of livelihood and income for the community, which will further help in overall development of community, village, district, state and nation as a whole [98, 99]. 
Table 4: Various programs recommended for facilitating adult education and lifelong learning programs

\begin{tabular}{|c|l|l|c|}
\hline Year & \multicolumn{1}{|c|}{ Programs } & \multicolumn{1}{|c|}{ Details } & Ref. \\
\hline 1990 & $\begin{array}{l}\text { Ram Murti Review } \\
\text { Committee }\end{array}$ & $\begin{array}{l}\text { National Literacy Mission (NLM) and } \\
\text { Mahila Samakhya should be well utilized } \\
\text { for integrating momentum into adult } \\
\text { education program }\end{array}$ & [51] \\
\hline 1996 & $\begin{array}{l}\text { European Year of Lifelong } \\
\text { Learning }\end{array}$ & $\begin{array}{l}\text { Identified four pillars of an individual } \\
\text { development namely; learning to be, } \\
\text { learning to know, learning to do and } \\
\text { learning to live together. }\end{array}$ & [52,53] \\
\hline 2002 & $\begin{array}{l}\text { The Hyderabad Statement } \\
\text { on Adult and Lifelong } \\
\text { Learning }\end{array}$ & $\begin{array}{l}\text { Lifelong education requires horizontal } \\
\text { integration and vertical articulation with } \\
\text { dynamic approach and using alternative } \\
\text { patterns. }\end{array}$ & [52-55] \\
\hline $\begin{array}{l}\text { Four dimensions of } \\
\text { lifelong learning approach } \\
\text { namely; target groups, } \\
\text { knowledge, contents and } \\
\text { systems }\end{array}$ & $\begin{array}{l}\text { Target groups inculcate children, youths, } \\
\text { workers and aging. Organization for } \\
\text { Economic Cooperation and Development } \\
\text { (OECD) determines various aspects of } \\
\text { lifelong learning that leads to an enriching } \\
\text { life of self-fulfilment. }\end{array}$ & [56,57] \\
\hline
\end{tabular}

\section{SUGGESTIONS FOR LIFELONG LEARNING PROGRAMS :}

For attaining sustainable economic structure, six programs for implementing lifelong learning programs were constituted by Turkish Republic European Union Ministry in 2011 as demonstrated in table 5 [56]. The major thematic areas required to be understood before initiating adult education program are learning characteristics, attitude, market, regulatory forces, social and economic policies, organizational climate and participating populations [100-102].

Table 5: Six programs for lifelong learning projects

\begin{tabular}{|c|c|l|l|}
\hline $\begin{array}{c}\text { S. } \\
\text { No. }\end{array}$ & Program & \multicolumn{1}{|c|}{ Aim of the program } & \multicolumn{1}{|c|}{ Details } \\
\hline 1. & Erasmus & $\begin{array}{l}\text { To foster collaboration between } \\
\text { higher education institutions }\end{array}$ & $\begin{array}{l}\text { To improve employment } \\
\text { opportunities for university graduates } \\
\text { by developing the system of higher } \\
\text { Education institutions in line with the } \\
\text { requirements of the business world. }\end{array}$ \\
\hline 2. & Comenius & $\begin{array}{l}\text { To imbibe cultural and moral } \\
\text { values among people }\end{array}$ & $\begin{array}{l}\text { Target audience are primary and } \\
\text { secondary institutes and other } \\
\text { educational faculties. }\end{array}$ \\
\hline 3. & Grundtvig & $\begin{array}{l}\text { To compete changing structure } \\
\text { of knowledge }\end{array}$ & $\begin{array}{l}\text { Focuses on imparting informal } \\
\text { education to adults }\end{array}$ \\
\hline 5. & Leonardo Da & $\begin{array}{l}\text { To amend and support } \\
\text { occupational education policies } \\
\text { of countries }\end{array}$ & $\begin{array}{l}\text { Occupational education and } \\
\text { Its related practices are the basis of } \\
\text { this programme. }\end{array}$ \\
\hline 6. & $\begin{array}{c}\text { Commo incentivize research and } \\
\text { intellectual activities in } \\
\text { European Integration studies }\end{array}$ & $\begin{array}{l}\text { Supports the institutions working } \\
\text { under this objective }\end{array}$ \\
\hline
\end{tabular}

Several studies have reported the concept of digital literacy as an imperative tool to extent lifelong learning program in current digital world [103-105]. Therefore, skill expertise in basic computer and 
orientation courses in computers are required for each individual to extent the scope of lifelong learning [106-109].

\section{CONCLUSIONS :}

Role of various platforms and policies imperative for implementation of various adult education programs strongly govern the effective spread of quality education among community. The successful implementation of policies depends on consortium of well trained, qualified and skilled stakeholders working towards a common domain. Adult education and lifelong learning programs are a significant source to obviate any impediments hampering development of an individual irrespective of age, profession, lifestyle and skills imparted. Therefore, NEP 2020 will serve as a valuable source for effective implementation of Adult education and lifelong learning program.

\section{REFERENCES :}

[1] Nedungadi, P. P., Menon, R., Gutjahr, G. (2018). Towards an inclusive digital literacy framework for digital India, Education and Training, 60(6), 516-528.

Google Scholar $\chi^{\top} \quad$ CrossRef /DOI $\chi^{\top}$

[2] Roberts, E., Farrington, J., Skerratt, S. (2015). Evaluating New Digital Technologies Through a Framework of Resilience, Scottish Geographical Journal, 131(3-4), 253-264.

Google Scholar X $\quad$ CrossRef/DOIX

[3] Gandhi, R. (2021). Review on the Key Features of the National Education Policy 2020 in the Context to Pre-school Education and its Expected Impact, International Journal of Management, Technology and Social Sciences (IJMTS), 6(1) 241-252.

\section{Google Scholar $\chi^{7} \quad$ CrossRef /DOI $x^{7}$}

[4] Kalyani, P. (2020). An Empirical Study on NEP 2020 [National Education Policy] with Special Reference to the Future of Indian Education System and Its effects on the Stakeholders, Journal of Management Engineering and Information Technology (JMEIT), 7(5), 1-17.

Google Scholar Х

[5] Aithal, P. S., Aithal, S. (2020). Analysis of the Indian National Education Policy 2020 towards Achieving its Objectives, International Journal of Management, Technology, and Social Sciences (IJMTS), 5(2), 19-4. Google Scholar $\chi^{7}$

[6] Gandhi, R. (2020). Impact of COVID-19 on Chandigarh-Its causes, consequences and role of community in preventing its transmission, International Journal of Applied Research, 6(4), 308313.

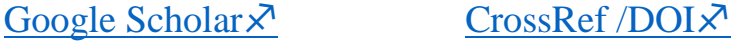

[7] Bekker, T., Bakker, S., Douma, I., van der Poel, J., \& Scheltenaar, K. (2015). Teaching children digital literacy through design-based learning with digital toolkits in schools. International Journal of Child-Computer Interaction, 5(1), 29-38. Google Scholar $X^{\top}$

[8] Aithal, P. S., Kumar, S. (2016) ABC Model of Research Productivity and Higher Educational Institutional Ranking. International Journal of Education and Management Engineering (IJEME), 6(6), 74-84.

Google Scholar 7

[9] Maruthavanan, M. (2020). A Study on the Awareness on New Education Policy (2019) among the Secondary School Teachers in Madurai District, International Journal of Education, 8(3), 67-71. Google Scholar $\chi^{\top}$

CrossRef /DOIX

[10] Midtsundstad, T. (2019). A review of the research literature on adult learning and employability, European Journal of Education, 54(1), 13-29. Google Scholar 7

CrossRef/DOIX

[11] Rubenson, K., Elfert, M. (2015). Adult education research: exploring an increasingly fragmented map, European Journal for Research on the Education and Learning of Adults, 6(2), 125-138. 


\section{Google Scholar $x^{7} \quad$ CrossRef /DOI $x^{7}$}

[12] Németh, B. (2014). Research and Development of Adult Education through Higher Education Institutions: A Challenge and Perspective for Better Adult Learning and Education, Procedia Social and Behavioral Sciences, 142(1), 97 - 103.

Google Scholar $X^{7} \quad$ CrossRef/DOIX

[13] Federighi, P. (2019). Research Methodology in Adult Learning and Education, Journal of Educational Sciences, 1(39), 58-73.

Google Scholar X

[14] Hieronymus, A. N. (1951) Research in Adult Education, The Phi Delta Kappan, 32(8), 373-375. Google Scholar ${ }^{\top} \quad$ CrossRef /DOI $x^{\top}$

[15] Nylander, E., Österlund, L., Fejes, A. (2018). Exploring the Adult Learning Research Field by Analysing Who Cites Whom, Vocations and Learning, 11(1), 113-131.

Google Scholar $x^{7}$

[16] Hällsten, M. (2012). Is it ever too late to study? The economic returns on later tertiary degrees in Sweden. Economics of Education Review, 31(1), 179-194.

Google Scholar X'

[17] Bratsberg, B., Nyen, T., Raaum, O. (2020). Economic returns to adult vocational Qualifications, Journal of Education and Work, 33(2), 1-16.

Google Scholar $X^{\top} \quad \underline{\text { CrossRef /DOIX }}$

[18] Picchio, M., van Ours, J. C. (2013). Retaining through training even for older workers. Economics of Education Review, 32(1), 29-48.

Google Scholar $X^{\top}$

[19] Civera, A., Lehmann, E. E., Paleari, S., Stockinger, S.A.E. (2020). Corrigendum to "Higher Education Policy: Why hope for Quality when rewarding Quantity?" Research Policy, 49(8), 104118.

Google Scholar X

[20] Freeman, S., Nguyen, T., Beliveau, J., M., Chung, R. J., Armstrong, S. ,M.D., Wolfe, C., Cholera, R., Wong, C.A. (2021). COVID-19 Response Strategies at Large Institutes of Higher Education in the United States: A Landscape Analysis, Fall 2020, Journal of Adolescent Health, 68(4), 683-685. Google Scholar X

[21] Aithal, P. S., Aithal, S. Shubhrajyotsna (2019). Analysis of Higher Education in Indian National Education Policy Proposal 2019 and its Implementation Challenges. International Journal of Applied Engineering and Management Letters (IJAEML), 3(2), 1-35.

Google Scholar X CrossRef /DOI X

[22] Dickson, N., Clover, D. E. (2021). Adult education, the arts and creativity, Studies in the Education of Adults, 53(2), 129-132.

Google Scholar $X^{\top}$

\section{CrossRef /DOIX}

[23] Shaw, C. R. (2021). Enhancing empathy and understanding of disability by using poetry in research, Studies in the Education of Adults, 53(2), 184-203.

Google Scholar 7 CrossRef /DOIX

[24] Palomar, J. D., Castillo, M. S. O., Pascual A. M., Oliver, E. (2021). Adults With Special Educational Needs Participating in Interactive Learning Environments in Adult Education: Educational, Social, and Personal Improvements. A Case Study, Frontiers in Pyschology, 1(1), 113.

Google Scholar $x^{7} \quad$ CrossRef /DOI $x^{7}$

[25] Loeng, S. (2020). Self-Directed Learning: A Core Concept in Adult Education, Education Research International, 1(1), 1-12.

Google ScholarX

CrossRef /DOIX 
[26] Tanjula, P., Christine, T. (2014). Approaches to a Successful Adult Education Program, College Student Journal, 3(8), 473-480.

Google Scholar $x^{7}$

[27] Candy, P. C. (1988). Key issues for research in self-directed learning, Studies in Continuing Education, 10(2), 104-124.

Google Scholar X

\section{CrossRef /DOIX}

[28] Cosnefroy, L., Carr'e, p. (2014). Self-regulated and self-directed learning: why don't some neighbors communicate?, International Journal of Self-Directed Learning, 11(2), 1-12. Google Scholar $x^{\top}$

CrossRef /DOIX

[29] Ryan, T. G., and Griffiths, S. (2015). Self-advocacy and its impacts for adults with developmental disabilities. Australian Journal of Adult Learning, 55(1), 31-53.

Google Scholar X

[30] Morais, M. M., Rapsová, L. (2019). Psychological bases of developing social competences of seniors with disability. Australian Journal of Adult Learning, 59(2), 269-292.

Google Scholar $X^{7}$

[31] Draper, E. A., Brown, L. S., Jellison, J. A. (2019). Peer-interaction strategies: fostering positive experiences for students with severe disabilities in inclusive music classes, Journal of Research in Music Education, 37(3), 28-35.

Google Scholar $x^{7}$

CrossRef /DOIX

[32] Villardon, A, F., Alvarez, P., Ugalde, L., and Tellado, I. (2020). Fostering the social development of children with special educational needs or disabilities (SEND) through dialogue and interaction: a literature review. Social Sciences, 9(6), 97.

$\underline{\text { Google Scholar } 7 \text { CrossRef/DOIX }}$

[33] Boyadjieva, P., and Ilieva-Trichkova, P. (2018). Adult education as a common good: conceptualisation and measurement, International Journal of Lifelong Education, 37(3), 345-358. Google Scholar $x^{\top}$

CrossRef/DOIX

[34] Buchanan, D., and Warwick, I. (2020). Supporting adults with mental health problems through further education, Health Education Journal, 79(8), 863-874.

Google Scholar X

CrossRef /DOI $x^{\top}$

[35] Buchanan, D (2014) A phenomenological study highlighting the voices of students with mental health difficulties concerning barriers to classroom learning, Journal of Further and Higher Education, 38(3), 283-446.

Google Scholar $x^{7}$

\section{CrossRef /DOIX}

[36] Shubenkova, E.V., Badmaeva, S.V., Gagiev, N.N., Pirozhenko, E.A. (2017). Adult education and lifelong learning as the basis of social and employment path of the modern man, Revista Espacios, $38(25) 1-11$.

Google Scholar $x^{7}$

[37] Bolhuis, S., Voeten, M. J. (2001). Toward Self-directed Learning in Secondary Schools: What Do Teachers Do? Teaching and Teacher Education, 17(7), 837-855.

Google Scholar $x^{\top}$

[38] Francom, G. M. (2010). Teach Me How to Learn: Principles for Fostering Students' Self-directed Learning Skills, International Journal of Self-directed Learning, 7(1), 29-44.

Google Scholar X

[39] Jossberger, H., S. Brand-Gruwel, H. Boshuizen, and M. Van de Wiel. (2010). The Challenge of Self-directed and Self-regulated Learning in Vocational Education: A Theoretical Analysis and Synthesis of Requirements, Journal of Vocational Education and Training, 62(4), 415-440. Google Scholar $\chi^{\top}$ CrossRef /DOIX 
[40] Loyens, S. M., Magda, J., Rikers, R. M. (2008). Self-directed Learning in Problem-based Learning and Its Relationships with Self-regulated Learning, Educational Psychology Review, 20(4), 411427.

Google Scholar $x^{\top}$

[41] Kaurav, R. P. S., Suresh, K. G., Narula, S., Baber, R. (2020). New education policy: Qualitative (contents) analysis and twitter mining (sentiment analysis), Journal of Content, Community and Communication, 12(6), 4-13.

Google Scholar $x^{\top}$

[42] Power, C. N., Maclean, R. (2012). Lifelong Learning: Meaning, Challenges, and Opportunities, Skills Development for Inclusive and Sustainable Growth in Developing Asia-Pacific: Technical and Vocational Education and Training: Issues, Concerns and Prospects, 19(1), 29-42.

\section{Google Scholar 7 CrossRef/DOI 7}

[43] Chiţiba, C. A. (2012). Lifelong learning challenges and opportunities for traditional universities, Procedia - Social and Behavioral Sciences, 46(1), 1943 - 1947.

Google Scholar $X^{\top}$

[44] Arini, McNaughton, S., Langley, J., Sauni, P. (2007). What education reform means: Lessons from teachers, research and policy working together for students' success, Educational Research for Policy and Practice, 6(1), 31-54.

Google Scholar 7

CrossRef /DOIX

[45] Power, C. N. (2009). Asia and the Pacific in 2020: Scenarios for educational research. Educational Research for Policy and Practice, 8(2), 81-93.

Google Scholar $X^{7} \quad$ CrossRef /DOI $X^{\top}$

[46] Cheng Y.C. (2007) Future developments of educational research in the Asia-Pacific Region: Paradigm shifts, reforms and practice, Educational Research for Policy and Practice, 6(2), 71-85 Google Scholar $x^{\top}$

CrossRef /DOIX

[47] Bear, A. A. G. (2012). Technology, Learning, and Individual Differences, Journal of Adult Education, 41(2), 27-42.

Google Scholar ${ }^{7}$

[48] Smith, R. M. (1991). How people become effective learners. Adult Learning, 2(6), 11-13. Google Scholar $X^{\top} \quad$ CrossRef /DOI $X^{\top}$

[49] Chan, B. T. Y. (2009). Conceptualising adult and continuing education practice: towards a framework for research, Australian Journal of Adult Learning, 49(1), 9-33.

Google Scholar X

[50] AlSaadat, K. (2018). Adult learning - theories methods and techniques, European Journal of Social Sciences Studies, 2(10), 37-47.

Google Scholar ${ }^{7}$

CrossRef /DOIX

[50] Bordoloi, R., Das, P., Das, K. (2020). Lifelong learning opportunities through MOOCs in India, Asian Association of Open Universities Journal, 15(1), 83-95.

Google Scholar $7 \quad$ CrossRef/DOI 7

[51] Singh, A. (1991). Ramamurti Report on Education in Retrospect, Economic and Political Weekly 26(26), 1605-1613.

Google Scholar $\chi^{\top}$

[52] Mandal, S. (2019). The rise of lifelong learning and fall of adult education in India, London Review of Education, 17(3), 318-330

Google Scholar $\chi^{3}$

CrossRef /DOIX

[53] Aggarwal, V. S. (2012). Lifelong Learning: The Challenge in Context of India, Research Journal of Social Science and Management, 1(12) 1-9.

Google Scholar $X^{7}$ 
[54] Antunes F. (2020). Europeanisation and adult education: Between political centrality and fragility. Studies in Continuing Education, 42(3), 298-315.

Google Scholar $x^{\top}$

CrossRef /DOIX

[55] Volles N. (2016). Lifelong learning in the EU: Changing conceptualisations, actors and policies. Studies in Higher Education, 41(2), 343-363.

Google Scholar X

CrossRef /DOIX

[56] Kaplan, A. (2016). Lifelong learning: conclusions from a literature: Review, International Online Journal of Primary Education, 5(2) 43-50.

Google Scholar $x^{7}$

[57] Jedlikowska, D. (2014). The students and teachers' mobility in the context of education. Global Journal of Information Technology, 4(2), 38-43.

Google Scholar X

[58] Asiksoy, G., Ozdamli, F. (2017). An overview to research on education technology based on constructivist learning approach, Cypriot Journal of Educational Sciences, 12(3), 133-147.

Google Scholar X'

[59] Milana, M. (2019). 3 Comparative and Global Policy Studies on Adult Education, Power and Possibility, 7(1), 27-37.

Google Scholar $x^{7}$

CrossRef /DOIX

[60] Strawn, J. (2007). Policies to promote adult education and post secondary alignment, Prepared for the National Commission on Adult Literacy, National Commission on Adult Literacy, 4(1), 1-28. Google Scholar X

[61] Reder, S. (2020). Developmental trajectories of adult education students: Implications for policy, research, and practice. In D. Perin (Ed.), The Wiley handbook of adult literacy, 2(1), 429-450.

Google Scholar $x^{7}$

CrossRef /DOI $x^{7}$

[62] Morrissey, M. (2002). Adult education and training: issues emerging from the perspective of the higher education sector and work organizations, A thesis submitted to Dublin city University for the degree of Doctor of Philosophy, 1(1), 1-419.

Google Scholar X

[63] Aker, J. C., Ksoll, C., Lybbert, T. J. (2012). Can mobile phones improve learning? Evidence from a field experiment in Niger, American Economic Journal: Applied Economics, 4(4), 94-120.

Google Scholar X

[64] Iivari, N., Sharma, S., Olkkonen, L.V. (2020). Digital transformation of everyday life - How COVID-19 pandemic transformed the basic education of the young generation and why information management research should care? International Journal of Information Management, 55(1), 102-183.

Google Scholar ${ }^{7} \quad \underline{\text { CrossRef /DOIX }}$

[65] Livingstone, S., Helsper, E. (2007). Gradations in digital inclusion: Children, young people and the digital divide, New Media \& Society, 9(4), 671-696.

Google Scholar $\chi^{\top} \quad$ CrossRef /DOI $x^{\top}$

[66] Mariën, I., Prodnik, A. (2014). Digital inclusion and user (dis) empowerment: A critical perspective, Info, 16(6), 35-47.

Google Scholar $x^{7}$ CrossRef /DOI $x^{7}$

[67] Crowther, J., Maclachlan, K., Tett, L. (2010). Adult literacy, learning identities and pedagogic practice, International Journal of Lifelong Education, 29(6), 651-664.

Google Scholar $X^{7} \quad$ CrossRef/DOIX

[68] Black, S., Yasukawa, K. (2013). Beyond deficit models for integrating language, literacy and numeracy in Australian VET, Journal of Further and Higher Education, 37(4), 574-590.

Google Scholar $x^{\top}$

CrossRef /DOIX 
[69] Amaral, M. P., Zelinka, J. (2019). Lifelong learning policies shaping the life courses of young adults. An interpretative analysis of orientations, objectives and solutions, Comparative Education, 55(3), 404-421.

Google Scholar $\chi^{7} \quad$ CrossRef /DOI $\chi^{7}$

[70] Levitt, K. A., Gardinier, M. P. (2021). Introduction contextualising global flows of competencybased education: polysemy, hybridity and silences, Comparative Education, 57(1), 1-18.

Google Scholar $x^{7} \quad$ CrossRef /DOIX

[71] Lee, M., Thayer, T., Madyun, N. (2008). The evolution of the European Union's lifelong learning policies: an institutional learning perspective, Comparative Education, 44(4), 445-463.

Google Scholar $x^{\top}$

CrossRef /DOIX

[72] Jarvis, P. (2014). From adult education to lifelong learning and beyond, Comparative Education, 50(1), 45-57.

Google Scholar $X^{7}$

CrossRef /DOIX

[73] Gough, I. (2015). The Political Economy of Prevention, British Journal of Political Science, 45(2), 307-327.

Google Scholar 7

CrossRef /DOIX

[74] Schneider, A., Ingram, H. (1993). Social Construction of Target Populations: Implications for Politics and Policy, American Political Science Review, 87(2), 334-347.

Google Scholar $X^{\top} \quad$ CrossRef /DOIX'

[75] Walther, A. (2006). Regimes of Youth Transitions. Choice, Flexibility and Security in Young People's Experiences Across Different European Contexts, Young, 14(2), 119-139.

Google Scholar X

CrossRef/DOIX

[76] Jessop, B. (2010). Cultural Political Economy and Critical Policy Studies, Critical Policy Studies, 3(3-4), 336-356.

Google Scholar ${ }^{7} \quad \underline{\text { CrossRef /DOI }} \chi^{7}$

[77] Barrett, A.M. (2007). Beyond the Polarization of Pedagogy: Models of Classroom Practice in Tanzanian Primary Schools, Comparative Education, 43(2), 273-294.

Google Scholar $X^{7} \quad$ CrossRef/DOIX

[78] Burns, Amy. (2017). A Cross Canada Inventory: Evidence of 21st Century Educational Reform in Canada, Interchange, 48(3), 283-292

Google Scholar X

[79] Barbier, C., Mayerhofer, W. L. (2004), The Many Worlds of Activation, European Societies, 6(4), 423-436.

Google Scholar X

CrossRef /DOIX

[80] Srinivas, T., Meenan, C.E., Drogin, E., DePrince, A. P. (2015). Development of the Community Impact Scale Measuring Community Organization Perceptions of Partnership Benefits \& Costs. Michigan Journal of Community Service Learning, 21(2), 5-21

Google Scholar $x^{\top}$

[81] Ferguson, H.B., Bovaird, S., Mueller, M.P. (2007). The impact of poverty on educational outcomes for children, Paediatr Child Health, 12(8), 701-706.

Google Scholar X

[82] Akareem, H.S., Hossain, S.S. (2016). Determinants of education quality: what makes students' perception different?, Open Review of Educational Research, 3 (1), 52-67.

Google Scholar $X^{7} \quad$ CrossRef/DOIX

[83] Li, Z., Qiu, Z. (2018). How does family background affect children's educational achievement? Evidence from Contemporary China, The Journal of Chinese Sociology, 5 (13), 1-21.

Google Scholar $X^{\top}$

CrossRef /DOIX 
[84] McClellan, J. A., Conti, G. J. (2008). Identifying the multiple intelligences of your students. Journal of Adult Education, 37(1), 1-20.

Google Scholar X

[85] Kok, I. (2013). A Study on the Relationship between Learners' Listening Comprehension Achievements and their Multiple Intelligence Groups, Procedia - Social and Behavioral Sciences, 89(1), $182-186$.

Google Scholar $x^{7}$

[86] Tough, A. (1978). Major learning efforts: Recent research and future directions, Adult Education, 28(1), 250-263

Google Scholar X

\section{CrossRef /DOI $x^{7}$}

[87] Añonuevo, C. M., Bernhard, A. (2011). Sustaining advocacy and action on women's participation and gender equality in adult education, International Review of Education, 57(1-2), 57-68.

Google Scholar X CrossRef/DOI X

[88] Berrozpe, T. I., Saso, C. E., Flecha, A., Marcaletti, F. (2020). Benefits of Adult Education Participation for Low Educated Women, Adult Education Quarterly, 70(1), 64-88.

Google Scholar $X^{7} \quad$ CrossRef/DOI ${ }^{\top}$

[89] Bukodi, E., Goldthorpe, J. H. (2012). Decomposing social origins: The effects of parents' class, status, and education on the educational attainment of their children, European Sociological Review, 29(1), 1024-1039.

Google Scholar X

\section{CrossRef /DOIX}

[90] Addae, D. (2021). Adults who learn: Evaluating the social impact of an adult literacy project in rural South Africa, Social Sciences \& Humanities Open, 3(1), 100115.

Google Scholar $X^{\top} \quad$ CrossRef /DOI $X^{\top}$

[91] Maruyama, H. (2009). Lifelong Learning for Sustainable Community Development in a Japanese Case, Educational Policy Analysis and Strategic Research, 4(1), 1-14.

Google Scholar $X^{\top}$

[92] Evans, P. (1996). Government Action, Social Capital and Development: Reviewing the Evidence on Synergy, World Developmen, 24(6), 1119-1132.

Google Scholar X

[93] Burt, R. (1997), The Contingent Value of Social Capital. Administrative Science Quarterly, 42(1), $339-65$.

Google Scholar $x^{7}$

[94] Mishra, L. (1998), National Literacy Mission: Retrospect and Prospect, Economic and Political Weekly, 33 (6), 2807-2815.

Google Scholar $x^{\top}$

[95] Weinstein, C., Ridley, D. S., Dahl, T., Weber, E. S. (1989). Helping students develop strategies for effective learning. Educational Leadership, 46(4), 17-19.

Google Scholar X

[96] Greenberg, D., Ehri, L., \& Perin, D. (1997). Are word-reading processes the same or different in adult literacy students and third-fifth graders matched for reading level? Journal of Educational Psychology, 89, 262-275.

Google Scholar $X^{7}$

CrossRef /DOIX

[97] Brooks, G., Torgerson, C. J., \& Porthouse, J. (2003). A systematic review and meta analysis of randomized controlled trials evaluating interventions in adult literacy and numeracy, Journal of Research in Reading, 26(3), 234-255.

Google Scholar $x^{\top}$

CrossRef /DOIX 
[98] Odoch, P. (2000). The Role of Adult Education and skills Training in promoting Planned Change and Localization: The Case of ACORD-NEBBI Community Development Programme in Uganda, Adult Education Research Conference, 1-7

Google Scholar X

[99] Jinna, Y. J., \& Maikano, P. N. (2014). The Role of Adult Education in National Development. International Letters of Social and Humanistic Sciences, 32, 35-42.

Google Scholar $\chi^{7} \quad$ CrossRef /DOI X

[100] Prete, A. D., Calleja, C., Cervera, M.M.G. (2011). Overcoming generational segregation in ICTs: Reflections on digital literacy workshop as a method, Gender Technology and Development, 15(1) 159-174.

Google Scholar 7

\section{CrossRef /DOIX}

[101] Crowther, J. (2004). In and against' lifelong learning: Flexibility and the corrosion of character, International Journal of Lifelong Education, 23(2), 125-136.

Google Scholar $X^{7} \quad$ CrossRef /DOI $\chi^{\top}$

[102] Black, L. W. (2012). Blog, chat, edit, text, or tweet? Using online tools to advance civic engagement, New Directions for Adult and Continuing Education, 135(1), 71-79.

Google Scholar $x^{\top} \quad$ CrossRef /DOI X'

[103] Spante, M., Hashemi, S. S., Lundin, M., Algers, A. (2018). Digital competence and digital literacy in higher education research: Systematic review of concept use, Cogent Education, 5(1), 1-21. Google Scholar $x^{\top}$

CrossRef /DOI $x^{\top}$

[104] Tang C. M., Chaw, L. Y. (2016). Digital Literacy: A Prerequisite for Effective Learning in a Blended Learning Environment?" The Electronic Journal of e-Learning, 14(1), 54-65.

Google Scholar X

[105] Nikou, S., Aavakare, M. (2021). An assessment of the interplay between literacy and digital Technology in Higher Education, Education and Information Technologies, 26(1), 3893-3915.

Google Scholar X

[106] Aish, A., Love, S. (2013). Factors influencing students' acceptance of m-learning: An investigation in higher education. The International Review of Research in Open and Distance Learning, 14(5), 82-107.

Google Scholar X

\section{CrossRef /DOI $X^{7}$}

[107] Alateyah, S., Crowder, R. M., Wills, G. B. (2013). Factors affecting the citizen's intention to adopt e-government in Saudi Arabia. International Journal of Social, Human Science and Engineering, 7(9), 80-85.

Google Scholar $X^{7}$

[108] Kember, D., McNaught, C., Chong, F.C.Y., Lam, P., Cheng, K.F. (2010). Understanding the Ways in Which Design Features of Educational Websites Impact upon Student Learning Outcomes in Blended Learning Environments, Computers and Education, 55(1), 1183-1192.

Google Scholar ${ }^{7} \quad$ CrossRef /DOIX

[109] Lawler, P.A. (2000). Ethical issues in continuing professional education, New directions for adult and continuing education, 86(1), 63-70.

Google Scholar 7 CrossRef /DOI $x^{\top}$

$* * * * * * * * * *$ 